Astrid Jensen*

\title{
Coping with Metaphor A cognitive approach to translating metaphor
}

\begin{abstract}
The present article focuses on the translation of metaphor by expert translators, young professional translators and non-professional translators. The approach adopted here treats translation of metaphor as a conceptual rather than a purely linguistic phenomenon, based on the framework sometimes referred to as conceptual metaphor theory (CMT), which is based on Lakoff \& Johnson (1980) and Lakoff \& Turner (1989). The basic assumption behind this study is that translating metaphor requires translator competence, which among other things entails an awareness of the duality of the metaphor as both a mental concept and linguistic expressions. It is further assumed that translation competence is developed through extensive training and translation experience. The study starts with a qualitative analysis of the metaphorical expressions and translation strategies in the sample texts, followed by a quantitative analysis whereby the frequencies of metaphor transference across languages and across groups are counted.
\end{abstract}

\section{Introduction}

The purpose of this study is to look at metaphor as a problem for translators, and to identify how professional translators and non-professional translators cope with that problem. I distinguish between professional translators at expert level, defined as more than 10 years of experience, professional translators with 2 years of experience and non-professional translators, with a degree in engineering (Jensen 2001).

In this article, metaphor is approached from a cognitive perspective, which treats metaphor as a conceptual rather than a purely linguistic phenomenon, based on the framework sometimes referred to as con-

\footnotetext{
* Astrid Jensen

Syddansk Universitet

Institut for Sprog og Kommunikation

Campusvej 55

$D K-5230$ Odense $M$

astrid@language.sdu.dk
}

Hermes, Journal of Linguistics no 35-2005 
ceptual metaphor theory (CMT) (Lakoff \& Johnson 1980; Lakoff \& Turner 1989).

This study is based on the assumption that translating metaphor is likely to require a specific translation competence, which includes a great deal of cross-cultural knowledge, but from a translator's perspective it also requires an awareness of the function of metaphor as well as an understanding of the duality of metaphor as both a mental concept and linguistic expressions (Andersen 2000).

The classic approach to metaphor translation merely sees metaphor as a characteristic of language. The focus is on linguistic differences between the source language and the target language and has led to numerous discussions about the translatability of metaphorical expressions, which again has led to the development of a number of prescriptive translation procedures. One of these translation procedures was developed by Newmark (1982), who distinguished between five types of metaphors: dead, cliché, stock, recent and original, and he listed seven main procedures for their translation (Newmark 1982: 85-91):

1: Reproducing the same image in the TL

2: Replace the image in the SL with a standard TL image

3: Translating metaphor by simile, retaining the image

4: Translation of metaphor (or simile) by simile plus sense

5: Conversion of metaphor to sense

6: Deletion

7: Same metaphor combined with sense

One major difference between the cognitive perspective and the classic one is that in cognitive linguistics, metaphor is not merely a linguistic style of expression; rather it is seen as a basic resource for thought processes. Such a perspective offers a different answer to the question of the translatability of metaphors, and even though it is not always possible to preserve an exactly equivalent metaphor when translating, the cognitive view of metaphor enables us to interpret metaphor in a more holistic way. Translatability is no longer a question of the individual metaphorical expression, but it becomes linked to the level of conceptual systems in source and target culture (Schäffner 2004). In terms of translation, Schäffner found that "a conceptual metaphor can 
be identical in the source text and the target text at the macro-level, without each individual manifestation having been accounted for at the micro level" (Schäffner 2004: 1267). Schäffner's example is the translation of the German 'Dach' (roof) into the English 'umbrella', which in both cases could be seen as metaphorical expressions of a more general conceptual metaphor BEING PROTECTED IS BEING UNDER A COVER. According to Lakoff and Johnson (1999), the same metaphorical mapping applied to different cultural images will give rise to different linguistic expressions of those metaphorical mappings, which also entails that different linguistic representations can be sanctioned by the underlying conceptual metaphor (Schäffner 2004).

Dealing with metaphor translation from a cognitive perspective is still rather unexplored, and has only recently been adopted in Translation Research (Andersen 2000; Schäffner 2004; Tirkkonen-Condit 2001).

\section{Some basic concepts}

This section starts by briefly examining the concept of metaphor, which can be used for a range of figurative language including metonymy, metaphorical idioms and mental imagery (which also includes simile). This broad perspective will be followed here. Metaphor theory will be supplemented with the concept of frames (Fillmore 1985) and profiling (Langacker 1987), and finally placed in the context of translation.

\subsection{Metaphor theory, frames and profiling}

\subsubsection{Metaphor}

The most important development in metaphor theory in the past 20 years has been the empirical work in cognitive science showing that metaphor is not merely a linguistic, rhetorical figure, but constitutes a fundamental part of people's ordinary thought, reason and imagination (Lakoff \& Johnson 1980, Lakoff 1987; Lakoff 1993; Lakoff \& Turner 1989; Gibbs 2004).

From a cognitive point of view, the crucial aspect of metaphor is its role in the structuring of an entire cognitive domain. Metaphors are a means of understanding one domain (target domain) in terms of another (a source domain), which cognitive linguistics refers to as metaphorical mapping across conceptual domains. The source domain is mapped 
onto the target domain. According to Lakoff \& Johnson (1980) it is important to realise that we do not just exploit the conceptual metaphor 'TIME IS MONEY' linguistically, but we actually think of, or conceptualise, the so-called target category TIME in terms of the source category MONEY, i.e. a valuable commodity and limited resource, when saying 'You are wasting my time'.

Cognitive metaphor theory claims to describe central processes and structures of human thought. The basic assumption behind the writing of Lakoff, Johnson and Turner is that, although metaphor is a conceptual phenomenon, we have access to the metaphors that structure our way of thinking through the language we use.

People rely on models of the concrete world to conceptualise abstract phenomena. Metaphor makes the abstract concrete. Our conceptualisation of models of abstract categories is grounded in our experience with people, everyday objects, actions and events.

Based on Joe Grady's theory of primary metaphor, Lakoff and Johnson (1998) have identified a number of primary metaphors that arise out of our embodied experiences of the world (Lakoff and Johnson 1998: 360-361):

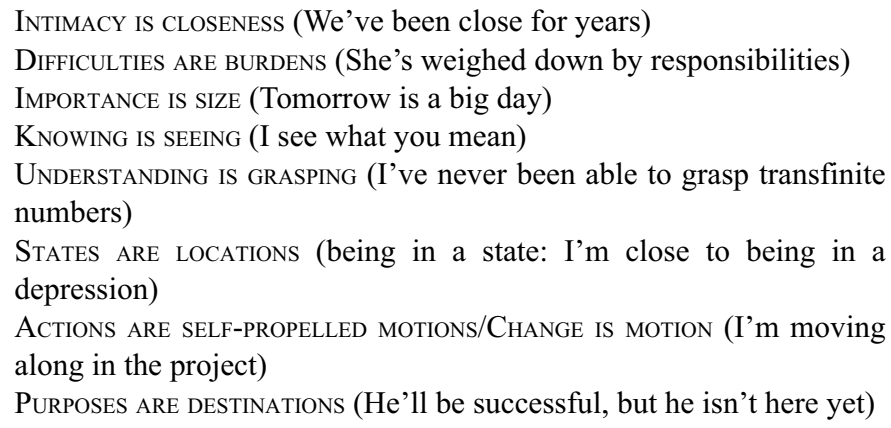

In each case the primary metaphorical mapping comes from the body's sensory-motor system. Complex everyday metaphors are built out of primary metaphors plus forms of commonplace knowledge: cultural models, folk theories, or simply knowledge or beliefs that are widely accepted in a culture (Lakoff and Johnson, 1998).

Many linguistic metaphors are idioms: spinning one's wheels, off the track, on the rocks, which are motivated by the metaphorical mapping in certain conventional mental images. In the expression 'we are spin- 
ning our wheels', used about a love relationship, the LOVE IS A JOURNEY metaphor maps conventional knowledge about cars, spinning wheels, the car being stuck, the traveller wishing the car to move, etc. onto knowledge about the love relationship. Lakoff \& Johnson (1999) refer to such idioms as metaphorical idioms. The words evoke an image, the image comes with knowledge, and conventional metaphors map appropriate parts of that knowledge onto the target domain. The result is the meaning of the idiom. Thus, a metaphorical idiom is not just a linguistic expression of a metaphorical mapping. It is the linguistic expression of an image plus knowledge about the image (Lakoff \& Johnson 1999: 373).

\subsubsection{Metonymy}

Like metaphor, metonymy is grounded in our experience, and it allows us to use one entity to stand for another. The difference between metaphor and metonymy is usually defined in terms of conceptual domains. In metaphor, there are two conceptual domains, and one is understood in terms of the other. Metonymy on the other hand involves only one conceptual domain. Metonymy has primarily a referential function, but it also serves the function of providing understanding. For example, in the case of the metonymy THE PART FOR WHOLE there are many parts that can stand for the whole. Which part we pick out determines which aspect of the whole we are focusing on. Often we find that a place may stand for an institution located at that place (Downing Street is not just an address in London, but stands for the British Government). Metonymies allow us to focus more specifically on certain aspects of what is being referred to (Lakoff \& Johnson, 1980:36-37). Metonymic mapping usually involves a direct physical or causal association, which makes it particularly context-dependent and culture specific, and as a writer usually writes for people, who share a certain amount of cultural background information with him/her, a substantial amount of information is left implicit in most texts. It is therefore important for the translator to take the whole context into consideration before inferring the potential meaning of a metonymy. 


\subsubsection{Frames and profiling}

As mentioned above, understanding metaphor and metonymic expressions requires knowledge of relevant domains. In order to understand a target domain in terms of a source domain, we must have knowledge of the source domain as well as an understanding of the target domain. Particular elements of the source and target domains are selected, and our knowledge of these domains - presumably stored as frames in long-term memory - tells us how elements in the two domains are structured against each other (Lakoff \& Turner 1989: 60-61). Fillmore (1985) defined frames as "specific unified frameworks of knowledge or coherent schematisations of experience" (1985: 223). Our understanding of the LIFE IS A JOURNEY metaphor uses our knowledge frame about journeys. For instance, all journeys involve travellers, places where we start, places where we have been. This knowledge has a framework that enables us to distinguish journeys from other kinds of activities (Lakoff \& Turner 1989: 60-61).

The concept frame is also closely associated with the notion of profiling. Profiling is a term used by Langacker (1987), and it essentially refers to the process of foregrounding or highlighting some element (or elements) within a frame. Any lexical item or grammatical form can be thought as foregrounding some aspect of our cognitive or social experience. Thus, the function of the word weekend is precisely to focus on two particular days of the week, demarcated from other days by our patterns of social behaviour. In this case, the profiled element and the frame stand in a part-whole relationship to each other. Weekend profiles a part of the concept 'seven-day week' in much the same way that knuckle profiles a specific part of the finger, or uncle profiles a specific part of the kinship network (Langacker 1987).

\subsection{Metaphor and Translation}

We are usually capable of understanding the meaning of metaphorical utterances effortlessly in our native language, and in most cases we do not even have to consciously process the underlying metaphor; the surface form seems to be translated into meaning almost instantly (Saygin 2001). A number of cross-linguistic studies have investigated the possibility that metaphors are not language-specific (Deignan et al. 2004; Gibbs 2004). Gibbs (2004) examined metaphor used to talk 
about desire in English and Portuguese, and he suggests that people's understandings of metaphorical expressions about human desires are motivated by their embodied experiences related to feeling hunger (DESIRE IS HUNGER). Examples that reflect this metaphor are He hungers for recognition and He was thirsty for power (Gibbs 2004: 1199). His findings showed that experiences of hunger appeared to structure significant aspects of the understandings of desire in both American English and Brazilian Portuguese. His basic claim is that "a significant aspect of metaphoric language is motivated by embodied experience" (Gibbs 2004: 1200). Further, Gibbs argues that complex metaphors, or linguistic expressions that are not closely connected to metaphorical concepts grounded in our embodied experience, are likely to be difficult to translate (Gibbs 2004: 1208), and as these metaphors usually come with a conventional mental image and commonplace knowledge, we may find considerable cultural problems when translating metaphorical expressions.

On the translation of metaphors, Dobrzynska (1995) says: "metaphor is an interpretative problem, and is strongly culturally conditioned; another language means another cultural background, and another conceptual system of the target readers" (1995: 597). Consequently, translating metaphor and metonymic expressions requires knowledge of source domains and target domains of two cultures. But translating metaphor also requires a thorough understanding of the function of the metaphor in the text. The translator needs to be aware of the cohesive force of metaphors, as well as the fact that metaphoric language adds an element of ambiguity and a possibility, or even a necessity, of different interpretations to the text. Lakoff and Johnson (1989: 64) refer to the "sources of power of metaphor", one of which is the power of options. Metaphorical mapping offers a number of optional components, as schemas are very general and "the components of a schema are slots that can be filled in by more specific information" (Lakoff and Johnson 1988: 64). Therefore, when paraphrasing a metaphor the translator, and not the target reader, disambiguates the text by selecting one 'right' interpretation of the metaphor. If the translator infers a meaning not intended by the source text writer, the text as a whole may create a different meaning and effect in the target text than in the source text. 


\section{Translation competence}

A number of experiments comparing professional translators and student translators using think-aloud protocol data have shown that translator competence is built up over time as expertise develops (Gerloff, 1996; Jääskeläinen, 1999; Lörscher, 1991, 1996; Jensen 2001). This view is also supported by Shreve (1997: 133), who on the expert-novice issue writes: "Empirical differences indicate qualitative differences in the knowledge organizational structure associated with doing translation". In this Shreve refers to a mapping ability, which has to be learnt by experience gained during the process of translating.

In my PhD-study (Jensen 2001) three groups of translators were studied: A pair of professional translators at expert level, defined as more than 10 years of translation experience, a pair of professional translators with 2 years of experience in professional translation, and a pair of non-professional translators. The two non-professional translators had M.Sc. degrees in engineering and used English in their daily work, and the two groups of professional translators all held university degrees in translation. The focus of that study was the effect of time on cognitive processes and strategies in translation, and it covered a range of activities conducted during the translation process, using TAPbased (Think-Aloud Protocol data) research combined with Translogcomputer logging. Translog is a computer program that logs keyboard behaviour in real time (Jakobsen and Schou 1999) and makes it possible to analyse the translation process as it develops, as well as analysing the finished translations.

The findings were related to Bereiter and Scardamalia's (1987) two models of text composition. One model, dealing with writing as a complex, problem-solving task, is called the Knowledge Transforming model, the other model, dealing with writing as a natural, unproblematic task which makes use of existing cognitive structures, is called the Knowledge Telling model (Bereiter and Scardamalia 1987:6). The Knowledge Telling model has often been associated with terms such as 'novice' and 'immature' processing and the Knowledge Transforming model with a more sophisticated problem-solving behaviour. However, the study showed that the Knowledge Telling model, though originally intended to account for the cognitive processes of immature writers, also proved to be a useful strategy for routine processing, and thereby 
also able to account for expert translation processes. In the study, the models proved to be able to distinguish between the processing pattern of young professional translators, who exhibited a problem-solving behaviour similar to that predicted by the Knowledge Transforming model, and expert translators, who seemed to exhibit behaviour that could be accounted for by the Knowledge Telling model. It was argued that as translators become more proficient, Knowledge Transforming skills gradually become replaced by Knowledge Telling skills relying on stored knowledge structures available from memory. But as the non-professional translators also exhibited behaviour as predicted by the Knowledge Telling model, it became necessary to find ways to differentiate sufficiently between the experts and the non-professional translators. Therefore, the observable characteristics of the Knowledge Telling and the Knowledge Transforming models were supplemented with an adapted version of Gile's (1995) taxonomy of coping tactics ${ }^{1}$ in interpretation. The analysis of coping tactics showed that faced with a problem, non-professional translators favoured coping strategies that required less cognitive effort than those selected by professional translators, which had strong similarities with Knowledge Telling strategies, whereas professional translators (experts and young professionals alike) applied Knowledge Transforming strategies in response to problems. The expert translators' use of Knowledge Telling strategies in routine situations were seen as a way of reducing the general cognitive load and allowing resources to be allocated to problem-solving when needed.

The experiments were conducted in 1997 and 1998 and were not specifically designed to test hypotheses on metaphor translation. But in order to obtain a clearer picture of possible differences between nonprofessional translators and professional translators, I now decided to take a closer look at one of the problem areas of the source texts: Metaphor.

\footnotetext{
1 The coping tactics selected were: Borrowing, transcoding, omitting information, reconstructing the segment with the help of context. Knowledge Telling Strategies were here identified as borrowing, transcoding and omitting, which was based on their similarity with Kasper and Færch's ' Reduction strategies' (1986). Knowledge Transforming Strategies were identified as reconstructing the segment with the help of context (see Jensen 2001: 168).
} 


\section{Purpose of study}

The purpose of this study is to identify how professional translators and non-professional translators cope with the translation of metaphor.

It is assumed that translating metaphorical expressions requires a specific competence, which includes cross-cultural knowledge, an understanding of the duality of metaphor as both a mental concept and linguistic expression, as well as an awareness of the textual function of metaphors. Further, it is assumed that translation competence develops through the experience of translating.

\section{Research design}

The present study starts with a qualitative analysis aimed at exploring the metaphorical expressions in the source texts, and to identify strategies related to the translation of metaphorical expressions. Out of the 27 metaphorical expressions identified in the source texts, I have selected 7 that will be analysed here as examples. The qualitative analysis will be followed by a quantitative analysis in which the frequencies of different metaphorical strategies across the three groups of translators are counted.

\subsection{The source texts}

The analysis is based on the three texts (Appendix 1) used in the original data corpus (Jensen 2001), and I identified a total of 27 metaphorical and metonymic expressions in the texts. The identification of metaphors and metonymies was based on my own intuition, and even though it would be possible to find other metaphorical expressions than the ones I have identified, I expect to have included the most important ones.

\subsection{The data}

The texts were translated from English into Danish, the latter being the mother tongue of all six informants. The informants were told to translate the articles as if they were going to appear in Berlingske Tidende, a well-known Danish quality newspaper with a national circulation. All informants were allowed to use dictionaries of their own choice, and in order to obtain as authentic translation situations as 
possible, the experiments took place in the informants' own offices, or in their homes, without intervention from the researcher.

The informants had been chosen to represent different levels of proficiency in translation. Of the six persons who volunteered to take part in the experiment, two were professional translators with 10 years of experience, two were professional translators with 2 years of experience, and the remaining two informants were not professional translators. The analysis is based on the above three source texts translated by the above six translators, i.e. 18 printouts from Translog, supplemented with comments from 18 transcribed Think-Aloud protocols. The transcriptions of the Think-Aloud protocols were not the primary material for my analysis and were only included when relevant.

\subsection{Coding translation strategies}

In order to identify how the translators transfer metaphors I identified a number of strategies, based on Andersen (2000), and adopted for the present purpose.

1: Use an equivalent of the original metaphor, which would express a similar conceptual mapping $(\mathrm{M} \rightarrow \mathrm{M})$

2: Replace a metaphor of the original with a metaphor based on a different conceptual metaphor $(\mathrm{M} \rightarrow \mathrm{D})$

3: Replace a metaphor with a paraphrase $(\mathrm{M} \rightarrow \mathrm{P})$

4: Deletion - a complete deletion of the metaphorical expression (Del)

\section{Qualitative analysis}

The purpose of the qualitative analysis is to identify metaphorical expressions in the texts and to categorise different translation strategies. I identified 27 metaphorical expressions, but I will limit myself to present seven randomly selected examples here. When relevant, I have supported the analysis with comments from the Think-Aloud protocols. 


\subsection{Identifying metaphor}

In the following analysis I have marked translator groups as $(E)=E x-$ pert, $(\mathrm{Y})=$ young professional $(\mathrm{NP})=$ Non-professional.

\section{Example 1:}

Source text segment:

Unit trust advertising: Wrapped in weasel words

Examples from Translog:

(NP) Deleted

(NP) Deleted

(Y) Deleted

(Y) Som uld i mund $(\mathrm{M} \rightarrow \mathrm{D})$

[TR: Talking woolly]

(E) Tom og tvetydig terminology $(\mathrm{M} \rightarrow \mathrm{D})$

[TR: empty and ambiguous terminology]

(E) Fulde af tvetydigheder $(\mathrm{M} \rightarrow \mathrm{D})$

[TR: Full of ambiguities]

Only three out of the six informants translated the metaphorical expression (the two expert translators and one of the young professionals), three of the informants deleted the metaphor.

Weasel words is a metaphorical idiom, based on an image metaphor popularised by Theodore Roosevelt in 1916, and explained as follows: "When a weasel sucks an egg, the meat is sucked out of the egg, and it leaves the shell" (Brewer's Dictionary of Phrase and Fable). The metaphor is conceptual, and maps certain features or activities that relate to an image.

As mentioned in chapter 2.2 we may find important cultural differences when translating metaphorical idioms, as they are based on mental images that can be highly culture specific. This seemed to be the problem with this metaphor, and it obviously challenged all the informants. Mostly because the phrase weasel words was unknown to them all, which could be seen from the protocols (the intensive use of dictionaries, corrections during processing, and the fact that three out of six informants chose to delete the entire sentence). The expression as a whole is used metaphorically to mean something like, wrapped in words without meaning, (indsvøbt i tom retorik) and from a conceptual perspective, we can say that rendering Wrapped in weasel words with Tom og tvetydig terminology (empty and ambiguous terminology), Fulde af tvetydigheder (full of ambiguities), could be sanctioned by the 
conceptual metaphor wORDS ARE OBJECTS, and WORDS ARE CONTAINERS OF MEANING, (empty words are empty containers). The translation Som uld i mund (talking wooly) could be conceptualised as WORDS ARE OBJECTS, and whether words can be understood or not depend on their degree of solidity (hard evidence, woolly ideas). However, as it was impossible to transfer the weasel image into Danish, and no one did, I categorised all three translations as metaphorical expressions based on a different conceptual metaphor $(\mathrm{M} \rightarrow \mathrm{D})$.

The following comment from a Think-aloud protocol shows how one of the translations developed from a process of creative image associations:

\section{Think-aloud protocol:}

Weasel words, jeg ved ikke lige hvad det betyder. Jeg slår det lige op i Vinterberg, weasel er sådan et krybdyr - et væsel - her : en tvetydig bemærkning. - Men det er jo et billede, måske kunne man finde på noget andet - noget for sjov. Uld i mund - ja det er det der ligger i det - som uld i mund.

[TR: Weasel words, I don't know what is meant by weasel word. I just have to look it up in Vinterberg (a dictionary). . a weasel is some kind of a reptile - a weasel - in the dictionary it says:' en tvetydig bemærkning' (double talk). - But it is an image, maybe I could find something else - for fun. Woolly - yes that's what it is - talking woolly ].

\section{Example 2:}

\section{Source text segment:}

"It is possible that no document on earth has committed as many sins against clear language.

\section{Examples from Translog:}

(NP) Intet dokument her på denne jord har syndet så meget $(\mathrm{M} \rightarrow \mathrm{M})$ [TR: no document here on this earth has committed as many sins ]

(NP) Intet dokument på jorden har begået så mange synder $(\mathrm{M} \rightarrow \mathrm{M})$ [TR: no document on earth has committed as many sins ]

(Y) Ikke noget andet dokument i verden har begået så mange syn$\underline{\operatorname{der}}(\mathrm{M} \rightarrow \mathrm{M})$

TR: no document in the world has committed as many sins] 
(Y) Det er umuligt at nogen anden tekst har forbrudt sig så eftertrykkeligt $(\mathrm{M} \rightarrow \mathrm{M})$

[TR: it is impossible that any other text has sinned so thoroughly]

(E) Intet dokument i verden der i den grad har syndet $(\mathrm{M} \rightarrow \mathrm{M})$

[TR: no document in the world has committed sins to this extent]

(E) Der er ikke noget andet dokument i verden der i den grad har forbrudt sig $(\mathrm{M} \rightarrow \mathrm{M})$

[TR: there is no other document in this world that has committed sins to this extent]

Personification: The metaphorical mapping teXts are human, enables us to place the document in agent position, which allows us to comprehend a wide variety of experiences with non-human entities in terms of human motivation, characteristics and activities. Texts can perform the same actions as humans. The phrase commit a sin evokes a RELIGIOUS frame profiling the element COMMITTING A SIN, which enables us metaphorically to map the documents (as human beings) to commit sins against the rules of clear language (humans commit sins against the laws of God).

The metaphor is conceptualised and lexicalised in the same way in Danish, and all six informants made this metaphorical mapping.

\section{Example 3:}

\section{Source text segment:}

"It is possible that no document on earth has committed as many sins against clear language.

\section{Examples from Translog:}

(NP) Intet dokument på jorden har begået så mange synder imod klar tale $(\mathrm{M} \rightarrow \mathrm{M})$

[TR: clear speech]

(NP) Intet dokument her på jorden har syndet så meget mod et forståeligt sprog $(\mathrm{M} \rightarrow \mathrm{P})$

[TR: understandable langauge]

(Y) Ikke noget andet dokument $\mathrm{i}$ verden har begået så mange synder mod klart sprog $(\mathrm{M} \rightarrow \mathrm{M})$

[TR: clear langauge] 
(Y) Det er umuligt at nogen anden tekst har forbrudt sig så eftertrykkeligt mod kravet om tydelig tale $(\mathrm{M} \rightarrow \mathrm{M})$

[TR: distinct speech]

(E) Der er ikke noget andet dokument i verden der i den grad har forbrudt sig mod kravet om et klart sprog $(\mathrm{M} \rightarrow \mathrm{M})$

[TR: clear language]

(E) Intet dokument $\mathrm{i}$ verden har i den grad syndet mod idealet om et tydeligt $\operatorname{sprog}(\mathrm{M} \rightarrow \mathrm{M})$

[TR: distinct language]

ABSTRACT IS CONCRETE: Language can be communicated or expressed in various ways, and whether it can be grasped or seen will depend on the degree of clarity; a clear object (language) is something that is easily seen/understood.

The metaphor is conceptualised and can be lexicalised in the same way in Danish and English. However, one of the informants (NP) chose to neutralise the metaphorical expression 'clear' by paraphrasing it to forståeligt sprog (understandable language). Five of the six informants kept the metaphor.

\section{Example 4:}

\section{Source text segment:}

The prose trips off the tongue like peanut butter

Examples from Translog:

(NP) Poetisk sprogbrug $(\mathrm{M} \rightarrow \mathrm{P})$

[TR: Poetic language]

(NP) Ordene glider på tungen som nøddesmør $(\mathrm{M} \rightarrow \mathrm{D})$

[TR: The words slip on the tongue as nut butter]

(Y) Sproget flyder som smør $(\mathrm{M} \rightarrow \mathrm{D})$

[TR: The language flows like butter]

(Y) Ordene klistrer fast i munden som peanut butter $(\mathrm{M} \rightarrow \mathrm{M})$

[TR: The words are glued to the mouth like peanut butter]

(E) Formuleringerne er som syltet ind i peanut butter $(\mathrm{M} \rightarrow \mathrm{D})$

[TR: The expressions are like jamed into peanut butter]

(E) Det hænger ved tungen som jordnøddesmør $(\mathrm{M} \rightarrow \mathrm{M})$

[TR: It sticks to the tongue as peanut butter] 
METONYMIC INTERACTION WITH METAPHOR: The metaphor is composed by a metonymic expression combined with an image metaphor. Tongue is often used metonymically to stand for speech, and the expression as a whole is used metaphorically to mean something like: the words get stuck in the mouth.

Metaphoric image mapping works in the same way as other metaphoric mappings. The example is different from the other metaphors in that it contains a comparison (simile). In this case, we do not map an expression from one domain onto another domain; we compare objects from two domains.

In the example, peanut butter is used metaphorically for 'glue', the meaning being that 'the prose gets glued to the tongue'. The words, however, do not tell us which qualities of peanut butter should be profiled, and looking at the translations it is obvious that we are dealing with cultural problems of profiling the relevant qualities of peanut butter, as peanut butter is a very popular food product in America, but not in Denmark. Further, the sentence seemed to contain an element of contradiction, as trips off seemed to be contradicted by peanut butter. The dictionary description for peanut butter is: a soft substance made of crushed peanuts. But is it soft? Sticky? Or slippery? This led to some confusion about the relevant qualities of peanut butter, and even though the meaning of the whole cannot be a simple function of the meanings of the parts, five of the informants processed the metaphor by processing its individual parts, and they insisted on keeping the peanut butter/ or butter image, which may create a different effect for the Danish reader compared to American source text reader.

From the above examples we see that the translators profile the qualities of peanut butter in very different ways, and from the following transcript from two of the think-aloud protocols, we see again how the translation of the metaphorical expressions developed from a process of image associations and knowledge activation:

Think-aloud protocol comments of one of the young professionals: The prose trips - jeg bliver nødt til at læse denne her sætning virkelig grundigt. The prose trips off - trips off the tongue like peanut butter - trips off, det vil sige det falder - med peanut butter, det klistrer så man næsten ikke kan synke, så det må være, at det jeg bliver nødt til at sige noget med at det klistrer på tungen. Jeg slår trips off op i den store eng-da ordbog. Jo, det er sådan noget med at snuble, falde. Trips off. 
Ordene, ordene hænger fast - det der billede. Det der billede - jeg skal prøve at finde et billede - ordene kan næsten ikke komme videre fra tungen ligesom peanut butter - ordene sætter sig fast.- 'Ordene klistrer fast i munden som peanut butter'.

[TR: The prose trips - I have to read this sentence really carefully. The prose trips off - trips off the tongue like peanut butter - trips off, it means something like falling off - with peanut butter, it is so sticky that you can hardly sink, so it must be.. that I have to say something like it is glued to the tongue. I will look up trips off in the big dictionary Eng-Da. Yes, it something like stumbling, falling. Trips off. The words, the words stick - that image. That image - I am trying to find an image - the words cannot get past the tongue, like peanut butter - 'Ordene klistrer fast i munden som peanut butter' ]

\section{Think-aloud protocol comments of another young professional:}

Sproget flyder - kunne man sige - det lyder også godt sammen med peanut butter - flyder, glider, flyder som ja, peanut butter - skal jeg skrive peanut butter [keep it in English] eller skal man skrive jordnøddesmør [translate it into Danish], som smør bare.

[TR: The language flows - one could say - yes, that works nicely together with peanut butter - flow, flow like, yes, peanut butter - should I write peanut butter or should I write jordnøddesmør, 'like butter ' only]

\section{Example 5:}

\section{Source text segment:}

He condemned the "Shroud of jargon and arcane language" of documents..

\section{Examples from Translog:}

(NP) Deleted

(NP) Deleted

(Y) Han fordømte dette gammeldags og uigennemsigtige sprog $(\mathrm{M} \rightarrow \mathrm{P})$

[TR: He condemned this old fashioned and opaque language]

(Y) .. og sagde at teksterne var fyldt med koder, og meget mystiske $(\mathrm{M} \rightarrow \mathrm{P})$

[TR: and said that the texts were filled with codes, and very mysterious] 
(E) Han fordømte det dække af jargon og forblommet sprog $(\mathrm{M} \rightarrow$ M)

[TR: He condemned the cover of jargon and equivocal language]

(E) Han fordømte det tågeslør af jargon og indforstået snak $(\mathrm{M} \rightarrow$ M)

[TR: He condemned the veil of misty jargon and informed talk]

UNDERSTANDING IS SEEING: Something that is easy to understand is clear or transparent. Knowledge/understanding that is unavailable is obscured, hazy, clouded, veiled. The metaphor is conceptualised in the same way in Danish and English. Only the two expert translators kept the metaphor, but with different linguistic manifestations, doekke (cover) and tågeslør (veil of mist), the young professionals paraphrased the metaphor, and the non-professionals deleted it.

\section{Example 6:}

\section{Source text segment:}

...the huge influx of new investors moving from US deposit accounts into share-based funds

\section{Examples from Translog:}

(NP) Deleted

(NP) Deleted

(Y) Nye investorer flytter deres opsparinger fra almindelige bankkonti til aktie investeringer $(\mathrm{M} \rightarrow \mathrm{M})$

[TR: ...investors are moving their savings from ordinary bank accounts to share-based ....]

(Y) Nye investorer i de seneste år har flyttet deres almindelige opsparinger til aktiebaserede inv. $(\mathrm{M} \rightarrow \mathrm{M})$

[TR: ...investors have moved their ordinary savings to share-based investments]

(E) Nye investorer, der I de senere år er gået fra amerikanske indlånskonti til investeringsforeninger $(\mathrm{M} \rightarrow \mathrm{M})$

[TR: ...investors have gone from American deposit accounts to unit trusts] 
(E ) Nye investorer, der er gået fra indlånskonti til aktiebaserede fonde I løbet af de sidste par år. $(\mathrm{M} \rightarrow \mathrm{M})$

[TR: ...investors have gone from deposit accounts to share-based fonds]

Four of the informants translated the metaphor by the same metaphor $(\mathbf{M} \rightarrow \mathbf{M})$, whereas the two non-professional translators deleted the entire metaphorical expression. In the following, the conceptual metaphors ACTIONS ARE MOTIONS and THE ECONOMY IS A PLACE account for monetary transactions as in: 'investors moving from US accounts into sharebased funds'.

We can conceptualise monetary processes, deposit accounts and funds in terms of actions and places. Accounts and funds are physical objects with an inside and an outside (Richardt 2003). We activate our knowledge frame of buildings and rooms, and investors can move from one building/room into another building/room - or metaphorically from one form of investment into another.

From a conceptual perspective, we can say that rendering 'from US deposit accounts into share based funds' with 'gået fra amerikanske indlånskonti til investeringsforeninger' is sanctioned by the metaphor: ACTIONS ARE MOTIONS AND ECONOMY IS A PLACE, and places can have boundaries, which may develop into the BUILDING metaphor in the context of economy.

\section{Example 7:}

Source text segment:

...in the pocket of John Major....

Examples from Translog:

(NP) Deleted

(NP) .. i lommen på John Major $(\mathrm{M} \rightarrow \mathrm{M})$

[TR: in the pocket of John Major]

(Y)... er John Majors forlængede arm $(\mathrm{M} \rightarrow \mathrm{D})$

[TR: John Major's extended arm]

(Y) .. i lommen på John Major $(\mathrm{M} \rightarrow \mathrm{M})$

[TR: in the pocket of John Major]

(E). .. i lommen på John Major $(\mathrm{M} \rightarrow \mathrm{M})$

[TR: in the pocket of John Major] 
(E). .. i lommen på John Major $(\mathrm{M} \rightarrow \mathrm{M})$

[TR: in the pocket of John Major]

This metaphorical idiom is conceptualised and lexicalised in the same way in Danish and English. Five out of the six translators kept the same conceptual metaphor and the same metaphorical expression. One of the young translators decided to change her first impulse, and write 'John Majors forlængede arm' [TR: extended arm] instead.

\section{Quantitative analysis}

The qualitative analysis enabled me to identify metaphorical expressions in the texts and to categorise different translation strategies. Based on the qualitative analysis and the assumption that translating metaphorical expressions requires a specific competence developed through experience, the following hypothesis was generated.

\section{Hypothesised effect of translator experience}

It is hypothesised that professional translators will aim at a metaphorical solution $(\mathrm{M} \rightarrow \mathrm{M}+\mathrm{M} \rightarrow \mathrm{D})$ when possible, whereas non-professional translators will aim at non-metaphorical solutions $(\mathrm{M} \rightarrow \mathrm{P}$ + Deletion).

\subsection{Findings}

The following is a quantitative analysis of the strategies applied by the different groups of translators when translating the 27 metaphorical expressions.

\begin{tabular}{|c|c|c|}
\hline Informants & $\begin{array}{c}\text { Metaphorical } \\
\text { solution } \\
\mathbf{M} \rightarrow \mathbf{M}+\mathbf{M} \rightarrow \mathbf{D} \\
\mathbf{\%}\end{array}$ & $\begin{array}{c}\text { Non-metaphorical } \\
\text { solution } \mathbf{M} \rightarrow \mathbf{P} \\
+\mathbf{D e l e t i o n} \\
\mathbf{\%}\end{array}$ \\
\hline Non-prof & 50 & 50 \\
\hline Young prof & 65 & 35 \\
\hline Experts & 87 & 13 \\
\hline
\end{tabular}

Table 7.1 Analysis of the metaphorical solution vs. non-metaphorical solution 
From table 7.1 we see that the hypothesised is partly confirmed. We observe a tendency towards metaphorical solution in both translator groups, young professionals (65\%) and experts (87\%) alike, whereas the group of non-translators applied both solutions equally often $(50 \%$ metaphorical solution and 50\% non-metaphorical solution).

To obtain a closer look at the distribution across all four strategies, I analysed to what extent the informants chose to translate metaphors with the same metaphor or a different metaphor, and to what extent deletion or paraphrasing strategies were selected.

\begin{tabular}{|l|c|c|c|c|}
\hline Informants & $\begin{array}{c}\mathbf{M} \rightarrow \mathbf{M} \\
\mathbf{\%}\end{array}$ & $\begin{array}{c}\mathbf{M} \rightarrow \mathbf{D} \\
\mathbf{\%}\end{array}$ & $\begin{array}{c}\mathbf{M} \rightarrow \mathbf{P} \\
\mathbf{\%}\end{array}$ & $\begin{array}{c}\text { Deletion } \\
\mathbf{\%}\end{array}$ \\
\hline Non-prof & 43 & 7 & 9 & 41 \\
\hline Young prof & 37 & 28 & 22 & 13 \\
\hline Experts & 59 & 28 & 13 & 0 \\
\hline
\end{tabular}

Table 7.2 Analysis of the translation of metaphor

From table 7.2 we see that the non-professional translators mainly applied two solutions. They either translated the source text metaphor by the same metaphor $(\mathrm{M} \rightarrow \mathrm{M}, 43 \%)$, or they simply deleted the metaphor (Deletion, 41\%). They rarely attempted to find a different metaphor $(\mathrm{M} \rightarrow \mathrm{D}, 7 \%)$, or paraphrase $(\mathrm{M} \rightarrow \mathrm{P}, 9 \%)$ the metaphor.

Comparing the use of deletion strategies of the non-professional translators with the two groups of professional translators, we find that the young professional translators only deleted $13 \%$ of the metaphorical expressions, and the experts did not delete any of them $(0 \%)$.

The young professional translators translated $37 \%$ of the metaphors by the same metaphor $(\mathrm{M} \rightarrow \mathrm{M})$, which is actually less than the non-professionals, who translated $43 \%$ of the metaphors by the same metaphor. Further, the young professional translators paraphrased more than any of the other groups $(\mathrm{M} \rightarrow \mathrm{P}, 22 \%)$.

The expert translators on the other hand clearly preferred to translate metaphors by metaphors. 59\% of all metaphorical expressions were translated by metaphors with similar metaphorical mapping $(\mathrm{M} \rightarrow \mathrm{M})$. 
The findings could be interpreted follows: The non-professional translators seem to process metaphors at the surface level; metaphors were translated by metaphors when an immediate match could be found in the target language, but faced with metaphorical translation problems this group used a reduction strategy and deleted the entire metaphor. The young professionals experienced more problems with metaphorical transfer than the expert group did, and one way of coping with that problem was by relying on associative processing, which entailed paraphrasing or an attempt of finding a different metaphor. This could be seen as a way of gradually developing the metaphorical competence we find with the expert group.

\section{Conclusion}

In this study it was assumed that translating metaphorical expressions requires competence developed through experience, and this competence would include cross-cultural knowledge, an awareness of the pragmatic, semantic and textual function of the metaphor, as well as an understanding of the duality of metaphors as both mental concepts and linguistic expressions.

One important feature of metaphoric language is that it adds an element of ambiguity and possible interpretations to the text, which means that any choice of metaphor or paraphrase of metaphorical expressions may have far-reaching semantic, pragmatic and cognitive consequences; if the translator infers a meaning not intended by the source text writer, the text may create a different meaning and effect in the target text than in the source text.

The purpose of this study was to identify how three groups of translators with different levels of experience coped with the translation of metaphors. It was hypothesised that professional translators would aim at metaphorical solution when possible, whereas the non-professional translators would apply non-metaphorical solutions.

The study was a combined qualitative and quantitative study, and the hypothesis was partly confirmed by the findings. Differences between the non-professional translators and the professional translators could be observed; but also differences between the young professionals and the expert translators were found in my data. 
The non-professional translators deleted $41 \%$ of the metaphors, which was interpreted as surface-level processing; faced with metaphorical problems the non-professional translators cope with that problem by applying a problem-solving strategy with minimum cognitive effort: Deletion. The analysis, however, also pointed at differences between expert translators and young professionals. The expert translators translated source text metaphors with the same metaphorical mapping to a much higher degree than the young professional translators did. The young professionals had more problems than the experts had, and they paraphrased more, which I interpreted as a way of actively coping with metaphors while developing expert metaphorical competence. The expert translators on the other hand seemed convincing in their ability to access conceptual metaphorical mapping across the language pairs in question, as well as an awareness of the function of the metaphor, which could be seen by their notable use of metaphorical solutions $(87 \%)$ when translating.

\section{References}

Andersen, Mette Skovgaard 2000: Metaforkompetence - En empirisk undersøgelse af semi-professionelle overscetteres metaforviden. Unpublished doctoral dissertation. Department of German. Copenhagen Business School.

Andersen, Mette Skovgaard 2002: Metaphernkompetenz semiprofessioneller Übersetzer? In Empirical Translation Studies, Process and Product. (= Copenhagen Studies in Language 27). Copenhagen: Samfundslitteratur, 55-83.

Bereiter, Carl/Scardamalia, Marlene 1987: The Psychology of Written Composition. Hillsdale, New Jersey: Erlbaum.

Deignan, Alice/ Potter, Lis 2004: A corpus study of metaphors and metonyms in English and Italian. In Journal of Pragmatics, Vol. 36, 1231-1252.

Dobrzynska, Teresa 1995: Translating metaphor: Problems of meaning. In Journal of Pragmatics, Vol. 24, 595-604.

Fillmore, Charles 1982: Frame semantics. In The Linguistic Society of Korea (eds). Linguistics in The Morning Calm, Seoul, South Korea: Hanshin Publishing, 111-137.

Fillmore, Charles 1985: Frames and the semantics of Understanding. In Quaderni di Semantica, VI, 2.

Færch, Claus/ Kasper, Gabriele 1986: One learner - two languages: Investigating types of interlanguage knowledge. In J. House and S. Blum-Kulka (eds). Interlingual and Intercultural Communication, Tübingen: Narr, 211-227.

Færch, Claus/ Haastrup, Kirsten/Phillipson, Robert 1984: Learner Language and Language Learning. Copenhagen: Gyldendal/Clevedon: Multilingual Matters. 
Gibbs, Raymond 2004: Metaphor is grounded in embodied experience. In Journal of Pragmatics, Vol. 36. 189-1210.

Gile, Daniel 1995: Basic Concepts and Models for Interpreter and Translator Training. Amsterdam: Benjamins.

Goatly, Andrew 1997: The Language of Metaphors. London and New York: Routledge.

Jääskeläinen, Riitta 1999: Tapping the Process: An Explorative Study of the Cognitive and Affective Factors Involved in Translating. Joensuu: University of Joensuu.

Jakobsen, Arnt Lykke 1998: Logging time delay in translation. In LSP texts and the process of translation (= Copenhagen Working Papers in LSP). Copenhagen: Business School, 73-100.

Jakobsen, Arnt Lykke / Schou, Lasse 1999: Translog documentation. In Probing the Process in Translation: Methods and Results. (= Copenhagen Studies in Language 24). Copenhagen: Samfundslitteratur, Appendix.

Jarvella, Robert/Jensen, Astrid/Andersen, Mette Skovgaard/Jensen, Elisabeth 2002: Towards characterizing translator expertise, knowledge and know-how: some findings using TAPs and experimental methods. In Riccardi, Alessandra (ed): Translation Studies, Perspectives on an Emerging Discipline. Cambridge: Cambridge University Press, 172-179.

Jensen, Astrid 2001: The effects of time on cognitive processes and Strategies in translation. Ph.D, (Copenhagen Working Papers in LSP). Copenhagen: Business School

Lakoff, George 1987: Women, Fire, and Dangerous Things, What Categories Reveal about the Mind. Chicago: University of Chicago Press.

Lakoff, George/Johnson, Mark 1980: Metaphors we live by. Chicago: University of Chicago Press,

Lakoff, George/Turner, Mark 1989: More Than Cool Reason: A Field Guide to Poetic Metaphor. Chicago: University of Chicago Press.

Lakoff, George/Johnson Mark. 1998: Philosophy in the Flesh. In Reading Material for Cognitive Sci 101/102, Spring 1998, University of California, Berkeley, 321-376.

Langacker, Ronald W. 1987: Foundations of Cognitive Grammar, Volume I, Theoretical Prerequisites. Stanford: Stanford University Press.

Newmark, Peter 1982: Approaches to Translation. Oxford: Pergamon Press.

Richardt, Susanne 2003: Metaphors in expert and common-sense reasoning. Text, Context, Concepts. Cornelia Zelinsky-Wibbelt (ed). Berlin. Mouton de Gruyter, 243298.

Saygin, Ayse Pinar 2001: Processing Figurative Language in a Multi-Lingual Task: Translation, Transfer and Metaphor. In Proceedings of Corpus-based \& Processing Approaches to Figurative Language Workshop, Corpus Linguistics 2001, Lancaster: Lancaster University, UK. 
Schäffner, Christina. 2004: Metaphor and translation some implications of a cognitive approach. In Journal of Pragmatics 36, 1253-1269.

Shreve, Gregory M./Diamond, Bruce J 1997: Cognitive processes in translation and interpreting: Critical issues. In Joseph Danks, Stephen Fountain, Michael McBeath and Gregory Shreve (eds). Cognitive Processes in Translation and Interpreting. London: Sage, 233-251.

Shreve, Gregory M. 1997: Cognition and the Evolution of Translation Competence. In J. Danks, S. Fountain, M. McBeath and G. Shreve (eds). Cognitive Processes in Translation and Interpreting. London: Sage, 120-136.

Tirkkonen-Condit, Sonja 1989: Professional vs. non-professional translation: A thinkaloud protocol study. In C. Séguinot (ed.). The Translation Process. Toronto: H.G. Publications, York University, 73-85.

Tirkkonen-Condit, Sonja 2001: Metaphors in translation processes and products. In Quaderns. Revista de traduccio 6, 11-15.

\section{Dictionaries and reference works:}

Collins English Dictionary 1994: Glasgow: HarperCollins Publishers.

Longman Dictionary of Language and Culture 1992: London: Longman

Nielsen, B. Kjærulff. 1996: Engelsk-Dansk Ordbog. Co.ed. Jens Axelsen. $3^{\text {rd }}$ edn. Copenhagen: Gyldendal.

Brewer, Ebenezer Cobham 1898: Brewer's Dictionary of Phrase and Fable. Philadelphia: Henry Altemus Company 


\section{Appendix 1}

Source: The Financial Times, March 15, 1997

No. of words: 118

Unit trust advertising: Wrapped in weasel words

"It is possible that no document on earth has committed as many sins against clear language. The prose trips off the tongue like peanut butter," Arthur Levitt, chairman of the US Securities and Exchange Commission, did not mince words when, as chief regulator, he condemned the "shroud of jargon and arcane language" of documents used to sell mutual funds, the local equivalent of UK unit trusts. "Poetry seems to be reserved for claims about performance, and conciseness for discussions about fees," he noted.

The SEC's concern over obfuscation has been heightened by the huge influx of new investors moving from US deposit accounts into share-based funds over the past few years.

\section{Source: The Observer, 1996}

No. of words: 121

Selective evidence of 'schools spin doctor'

His name is Chris Woodhead; he is the chief inspector of schools, waging war against weak and sloppy teachers. Or, as his critics prefer, he is a spin-doctor in the pocket of John Major and the anti-comprehensive zealots of the Downing Street Policy Unit.

On Tuesday, Mr Woodhead will present a report on reading standards in the three inner-London boroughs of Islington, Tower Hamlets and Southwark. It makes sorry reading: almost 80 per cent of seven-year olds below standard; teaching unsatisfactory in one in three lessons; weak headteachers. The report, which draws a grim scenario for working-class pupils, is classic Woodhead. And the culprit? The 'progressive' teaching ideology developed in the Sixties by left-leaning educationists. 
Source: The Economist, April 5, 1997

No. of words: 122

Splitting the brand

The scene: Saturday night in a flickering party tent beneath the Brandenburg Gate in Berlin. In front of it are 80 tonnes of snow, heaped into a snowboard ramp on which Europe's coolest swerve and flip. This is 'Urban High', an event where 20,000 clubbers dance to music provided by the Chemical Brothers. And what is the chemical that helps them climb higher? Er ... Scotch on the rocks. Urban High is sponsored by Ballantine's, the leading brand of Allied Domecq, the world's second-largest producer of Scotch whisky. Allied is not alone in trying to shed bagpipes and tartan in favour of drum machines and spandex. Guinness has tried to jump aboard the current craze in Britain for 'alcopops'. 
